\title{
Sly humour, masterful suspense in physician's first novel
}

Previously published at www.cmaj.ca

The Parabolist: A Novel

Nicholas Ruddock

Doubleday Canada; 2010.

I $\mathrm{n}$ years to come, I expect to look back fondly on the characters in this novel as if they were people I'd met and loved, yet foolishly allowed to slip away. Three medical students and the brilliant, masterful and murderous poet who wins their affections are at the heart of the story. Their foibles, passions and disasters linger in the mind.

In fact, everyone who crosses a page in The Parabolist is memorable, even those in the most minor walk-on part. Most are engaging and seductive, deserving of affection or sympathy. The students are especially worth watching. Valerie Anderson is a woman unconscious of her beauty and seemingly a magnet for love and dan-

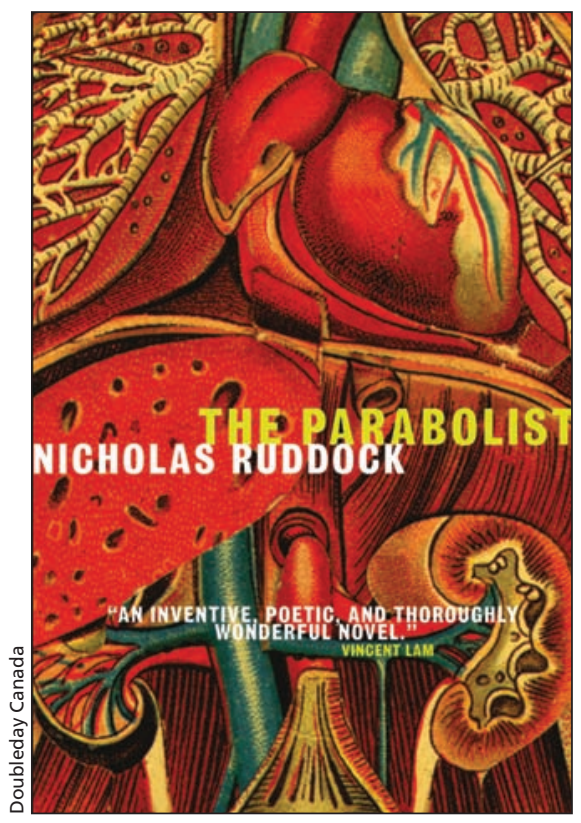

secrets of some surprising and cheerful sexual escapades.

Nicholas Ruddock, a family physician practising in Guelph, Ontario, has done a masterful job of integrating

\section{Ruddock casts quite a spell. This captivating book is poetic, yet light in spirit, languorous and seductive.}

gerous obsession. Her anatomy lab partner, Jasper Glass, is sweetly besotted and inclined to risky liaisons, while his younger brother, the hapless John Glass, manages to get tossed from medical school like a piece of debris. I felt I was at their sides in the anatomy lab as well as in on the
Roberto Moreno, the unlikely poetry instructor, into their midst. The mesmerizing Roberto, a passionate poet himself, is fresh from Mexico City where apparently poetry can be a matter of life or death. He is the burning centre of the story. Roberto can flash a poetic sentiment as fast as he can flick his switchblade. We soon suspect that trouble is inevitable.

Ruddock is able to foster fear for his characters, notably in the long harrowing ride of the 14-year-old teenage runaway from a Northern Ontario town to the bus station in Toronto where she encounters the man who will change her life. The threads that link the main characters with the young prostitute are intricately woven, as is the story of a woman who is the target of a vicious and random sexual attack. But even if there were no attacks, no rapes, no murders, no lives ruined and bodies damaged, even if nothing happened besides poetry, lovemaking and the occasional escape from an awkward extramarital interlude (you'll develop new respect for Crisco), this would still be a compelling book. Poetic, yet light in spirit, languorous and seductive, with a sly humour, and masterful suspense. Ruddock casts a quite a spell.

This first novel is almost impossible to categorize. Is it a literary work? A crime novel? An erotic comedy? In the end it makes no difference because it all comes together seamlessly. With luck it will be the first of many books Ruddock delivers to what should soon become an appreciative legion of readers.

\section{Mary Jane Maffini BA MLS \\ Mystery author \\ Ottawa, Ont.}

Mary Jane Maffini has published 12 mystery novels and nearly two dozen short stories. Her latest book, Law \& Disorder: A Camilla MacPhee Mystery, mainly takes aim at lawyers. 